\title{
ERBB4 wt Allele
}

National Cancer Institute

\section{Source}

National Cancer Institute. ERBB4 wt Allele. NCI Thesaurus. Code C52167.

Human ERBB4 wild-type allele is located within 2q33.3-q34 and is approximately $1156 \mathrm{~kb}$ in length. This allele, which encodes receptor tyrosine-protein kinase erbB-4 protein, is involved in the regulation of mitogenesis and differentiation. Mutations in this gene and overexpression are associated with several cancers, including breast cancer. 